\title{
Extracorporalis irradiatio: nagy csontdefektussal járó tumorresectiót követő biológiai rekonstrukció
}

\author{
Perlaky Tamás dr. ${ }^{1}$ - Kiss János dr. ${ }^{1}$ - Szalay Krisztián dr. ${ }^{1}$ \\ Moghaddam Amin Maysam dr. ${ }^{1}$ - Ágoston Péter dr. ${ }^{2}$. Szendröi Miklós dr. ${ }^{1}$ \\ ${ }^{1}$ Semmelweis Egyetem, Általános Orvostudományi Kar, Ortopédiai Klinika, Budapest \\ ${ }^{2}$ Országos Onkológiai Intézet, Sugárterápiás Központ, Budapest
}

Bevezetés: A malignus csonttumorok sebészi ellátása során kialakuló szegmentális csontdefektusok pótlása fontos szempont a végtagmegtartó sebészetben. Felnőttkorban a megoldás rendszerint tumorprotézis beültetése, 10 évesnél fiatalabb gyermekeknél azonban ez nehezen alkalmazható módszer a kis csontméret és az igen magas várható szövődményarány miatt. A bemutatott, hazánkban még ritkán alkalmazott beavatkozás, a tumoros csontszegmentum mütét alatti sugárkezelése, visszaültetése megfelelő rekonstrukciós lehetőség a végtag funkciójának megtartása mellett, csökkentve a későbbi reoperációk, protézisrevíziók számát.

Célkitüzés: A hazánkban eddig az ismertetett módon végzett mútétek bemutatása, az eredmények összevetése nemzetközi irodalmi adatokkal.

Módszer: Magyaroszágon eddig 12 alkalommal végeztünk végtagmegtartó mútétet malignus csonttumor miatt 12 évesnél fiatalabb gyermekeknél, és e mütétek során biológiai rekonstrukciós módszerként extracorporalis irradiatiót, autograft-reimplantatiót (ECRT, ECI) végeztünk. A mútétek mindegyike primer malignus csonttumor (Ewing-sarcoma 7 esetben, osteosarcoma 4 esetben, chondrosarcoma l esetben) miatt történt. Betegeink átlagéletkora 9 (3-12) év volt, az átlagos utánkövetési idő 32,5 (2-73) hónap. A felmérés során fizikális vizsgálat, valamint minden alkalommal röntgenfelvételek készítése történt, szükség esetén szövettani mintavétellel, vérelemzéssel vagy egyéb képalkotással kiegészítve. Eredményeinket nemzetközi irodalmi adatokkal hasonlítottuk össze.

Eredmények: Lokális tumorkiújulást egyetlen esetben sem észleltünk, másik csontot érintő skip ('ugró') metastasis miatt egy alkalommal amputatiót végeztünk. A szövődmények tekintetében eredményeink megfelelnek a nemzetközi irodalomban leírtaknak. Két esetben jelentkezett szeptikus szövődmény (16,7\%). A resectiós sík radiológiai átépülése 3-9 hónap alatt történt meg az esetek 60\%-ában. Álízület, grafttörés, graft részleges elhalása miatt 3 esetben végeztünk reoperációt, kétszer újabb allograft felhasználásával, egy esetben pedig tumorprotézis beültetésével. Betegeink szubjektív véleménye a módszerről pozitív, a legtöbb esetben megőrizték jó fizikai aktivitásukat, az esetleges reoperációk ellenére végtagjukat terhelik, akár sporttevékenységet is végeznek.

Következtetések: Vizsgálatunk alapján az extracorporalis irradiatio hasznos biológiai rekonstrukciós módszer 12 évesnél fiatalabb gyermekek esetében szegmentális csontdefektusok pótlására tumoros indikációval. A felmerülő szövődmények aránya alatta marad a hasonló korban beültetett tumorprotézisek szövődményarányainak, ideális esetben pedig több, további kiterjesztett mútét elkerülhető vele. Szövődmény esetén a későbbiekben tumorprotézis-beültetés mint végtagmegtartó vészmegoldás még mindig elvégezhető.

Orv Hetil. 2020; 161(45): 1914-1919.

Kulcsszavak: extracorporalis irradiatio, ECRT, ECI, allograft, végtagmegtartó sebészet, csonttumor

\section{Extracorporeal irradiation: biological reconstruction following tumor resection with a large bone defect}

Introduction: Reconstruction of massive segmental bone defects is a crucial point of limb salvage surgeries after malignant bone tumor resections. Megaendoprostheses implantation is a commonly used method for adult patients, but hardly usable for children below 12 years old, because of the small size of the host bone and multiple mechanic complications. 
Objective: Extracorporeal irradiation and allograft reimplantation (ECRT, ECI) are promising methods for these young children for limb salvage, reducing the number of prostheses revisions, reoperations.

Method: In Hungary, we performed limb salvage surgery for malignant bone tumor in 12 cases in children under 12 years old, using extracorporeally irradiated autografts as biological reconstruction. All cases were primary bone tumors (Ewing's sarcoma: 7, osteosarcoma: 4, chondrosarcoma: 1). The average age of our patients was 9 (3-12) years, the average follow-up was 32.5 (2-73) months. At follow-up, we performed physical examination, X-ray, and other imaging methods if they were necessary. Our results were compared to international publications.

Results: We observed no local recurrence, but in one case we had to perform above-knee amputation, due to a skip metastasis in the proximal tibia. The complication rates were similar to those reported in other papers. Septic complications were treated in two cases (16.7\%). Total union of the resection lines was observed at 3-9 months in $60 \%$ of all cases. Reoperations were performed due to nonunion, or allograft fracture/partly desorganization in 3 cases, twice with new allograft, and with prostheses in one case. The subjective opinion of our patients is positive, they walk with full weightbearing, some of them do even light sporting activities.

Conclusions: We found extracorporeal irradiation a useful and safe method for children under 12 years old for biological reconstruction after malignant bone tumor resection. Complication rate stays under the rate of growing prostheses complications, in optimal cases further radical, and extensive surgeries may be avoided. In the case of major complications, megaendoprostheses implantation later on is still an option as salvage procedure with limb salvage.

Keywords: extracorporeal radiation therapy, allograft, bone tumor, limb salvage, ECRT, ECI

Perlaky T, Kiss J, Szalay K, Moghaddam AM, Ágoston P, Szendrói M. [Extracorporeal irradiation: biological reconstruction following tumor resection with a large bone defect]. Orv Hetil. 2020; 161(45): 1914-1919.

(Beérkezett: 2020. február 25.; elfogadva: 2020. május 21.)

\section{Rövidítések}

$\mathrm{ECI}=$ extracorporalis irradiatio $; \mathrm{ECRT}=($ extracorporeal radia tion therapy) extracorporalis sugárterápia; $\mathrm{CT}=$ (computed tomography) számítógépes tomográfia; $\mathrm{MRI}=($ magnetic resonance imaging) mágnesesrezonancia-képalkotás; PET/CT = (positron-emission tomography/computer tomography) pozitronemissziós tomográfiával kombinált számítógépes tomográfia

A malignus csonttumorok az összes rosszindulatú daganat mintegy $0,5-1 \%$-át teszik ki. A leggyakoribb malignus csonttumorok közül az osteosarcoma és a Ewingsarcoma legjellemzőbb életkori megjelenése gyermekkorra, fiatal felnőtt korra tehető. A rosszindulatú csonttumorok rendszerint nagy malignitásúak, ezért a megfelelő radikalitás eléréséhez sokszor csonkítómútét szükséges. Végtagmegtartás esetén az érintett csont vagy akár ízület resectiója történik, melyet a keletkezett csontdefektus pótlása követ [1]. Szerencsére a korszerü diagnosztikai módszereknek és a korszerú kemoterápiának köszönhetően egyre nagyobb számban van lehetőség végtagmegtartó műtétek elvégzésére, és a betegek túlélési statisztikái is egyre javuló tendenciát mutatnak [2].

Felnőtt betegeknél a rekonstrukció rendszerint tumorendoprotézisek segítségével történik, gyors rehabilitációt, kiváló életminőséget biztosítva. Az ilyen protézisrendszerek azonban a későbbiek során további revíziókat igényelnek [3-5], többek között a protézissel kapcsolatos szövődmények miatt.

Fiatalabb életkorban egyre nagyobb teret hódít a különböző allograftok felhasználása, legyen szó akár fa- gyasztott, akár frissen beültetett vagy osteoarticularis csontszegmentumokról. Ezen graftok előnye a biológiai aktivitás, illetve rögzítési pontok biztosítása a leválasztott szalagok, izmok számára. A módszer rutinszerú alkalmazásához szükség van egy jól múködő csontbankra megfelelő számú donorral. Ez azért fontos, hogy a malignus csonttumorok ellátását megfelelően ki tudja szolgálni, ne kelljen a szükséges graftra várakozni [6]. Sikeres mütét esetén is jelentős számú és súlyosságú szövődménnyel kell számolni. Gyakori a késői hematogén infekció, valamint a graft törése [6-8]. A beültetést követően az allograft szerkezeti gyengülése következik be, vélhetően az át nem épülő microfracturák és a csökkent mineralizáció következtében, gyengítve a graft torziós stabilitását [9]. Késői problémának tekinthető az osteoarticularis graftok átültetését 5-6 évvel követő ízületi arthrosis kialakulása is [10]. 13-14 éves kor felett a csontok biológiai érésének köszönhetően jelentős végtageltérésekkel már kevésbé kell számolni, ilyenkor hagyományos tumorprotézisek beültetését végezzük.

A 10-12 évesnél fiatalabb gyermekeknél különösen problémás a nagy csontdefektusok pótlása, mivel ilyen kis méretben csak egyénre szabott protézisek rendelhetők hosszú átfutási idővel, igen drágán, melyeket a mưtétet követően rendszeresen reoperálni kell a csontok növekedése miatt [11]. 8 éves kor alatt rendszerint nem is javasolt tumorprotézis beültetése. Az ideális megoldás olyan csontgraft használata, mely méret- és formaazonos. Használata során nem kell kórokozók, tumorsejtek átvitelétől tartani. A graft megoldja a protézisek használata során fellépő csontveszteséget, szalagtapadási prob- 
lémákat, nem gátolja a megmaradó növekedési porcok múködését.

Hazánkban újonnan alkalmazott biológiai rekonstrukciós megoldás az érintett csontszegmentum resectiója, intraoperatív sugárkezelése, majd visszaültetése (extracorporalis irradiatio, ECRT, ECI). A módszert Uyttendaele és mtsai írták le 1988-ban; azóta több nagy betegszámú, hosszú utánkövetésû vizsgálat igazolta, hogy az eljárás megfelelő méretü, szilárdságú, biológiailag aktív graftot eredményez, mely szövődménymentes esetben akár életre szóló megoldást biztosíthat [6, 12, 13].

\section{Módszer}

Magyarországon, a Semmelweis Egyetem Ortopédiai Klinikáján eddig 12 alkalommal végeztünk végtagmegtartó mútétet primer malignus csonttumor miatt 12 évesnél fiatalabb gyermekeknél extracorporalis irradiatio és autograft-reimplantatio (ECRT, ECI) módszerével 2013 és 2019 között. Betegeink között 8 fiú-, 4 leánygyermek szerepelt. A diagnózisok eloszlása megfelelt a korábban közölt adatainknak [14], 7 esetben Ewing-sarcoma, 4 esetben osteosarcoma, 1 esetben chondrosarcoma miatt végeztünk végtagmegtartó mütétet.

Az átlagos utánkövetési idő 32,5 (min. 2, max. 73) hónap volt.

A mütéteket megelőzően minden betegnél feltárásos szövettani mintavétel történt, valamint a betegek teljes onkológiai 'staging' vizsgálatsorozaton estek át. A kezelési stratégiát multidiszciplináris klinikai onkoteamülés során határoztuk meg. Az osteosarcomás és Ewingsarcomás betegeink az aktuális protokollnak megfeleló neoadjuváns és adjuváns kemoterápiában részesültek. A tumor minden esetben egy csontot érintett, a leggyakrabban a femurt $(\mathrm{n}=7)$, a tibiát $(\mathrm{n}=4)$, majd a humerust $(\mathrm{n}=1)$. A reszekált csontszegmentumok hossza 10-22 cm között változott. A pontos resectiós síkot képalkotó vizsgálatok (CT, MRI, PET/CT) alapján határoztuk meg. Minden esetben széles resectio történt. A mútétek során mintavételt végeztünk a resectiós síkokból és a mintából, a sugárkezelés előtt és azt követően is. A tumoros csontszegmentumot a kiemelést követően letisztítottuk, majd 3 rétegben sterilen becsomagoltuk és az Országos Onkológiai Intézet Sugárterápiás Központjába szállítottuk, ahol megtörtént az ECI 100 Gy összdózisban. A szállítással együtt az egész eljárás mintegy 70 percet vett igénybe. Ez alatt az idő alatt megtörtént a recipiens terület előkészítése, alapos öblítés, vérzéscsillapítás. A besugarazást követően ismételt mintvételt végeztünk a tumoros csontból. A besugarazott graftot viszszaillesztettük a helyére, és a megmaradt eredeti csonthoz rögzítettük. Esetenként autológ fibulával is megerősítettük, stabil osteosynthesist hozva létre. A rögzítés módja attól függően változott, hogy intercalaris vagy osteoarticularis graftot ültettünk vissza. Intercalaris pozícióban egyszeres vagy kétszeres lemezelést, esetenként velőürszeget alkalmaztunk, két alkalommal pedig osteoarti- cularis graftoknál lemezes ostheosynthesis megoldást választottunk. A diaphysealis resectiós síkoknál hagyományos lemezeket használtunk, míg az ízülethez közeli resectiós síkoknál inkább szögstabil implantátumok beépítését részesítettük előnyben. Osteoarticularis graftot két esetben alkalmaztunk (distalis femur: 1, distalis humerus: 1). A rekonstrukció során minden szalagot, izomtapadást fúrt csatornák vagy horgonyok segítségével rögzítettünk vissza a csonthoz. A mútétet követően gipszsínt, majd ortézist helyeztünk fel 12-60 hétre. A végtag teljes terhelését nem engedtük 6-10 hónapig.

A helyi tumorkiújulást 3 havonta ellenőriztük röntgen-, CT- és MR-felvételekkel. A graft átépülését röntgen- és CT-vizsgálattal követtük, infekció kialakulását a klinikai jelek és laborvizsgálatok alapján ellenőrizük (1. ábra).
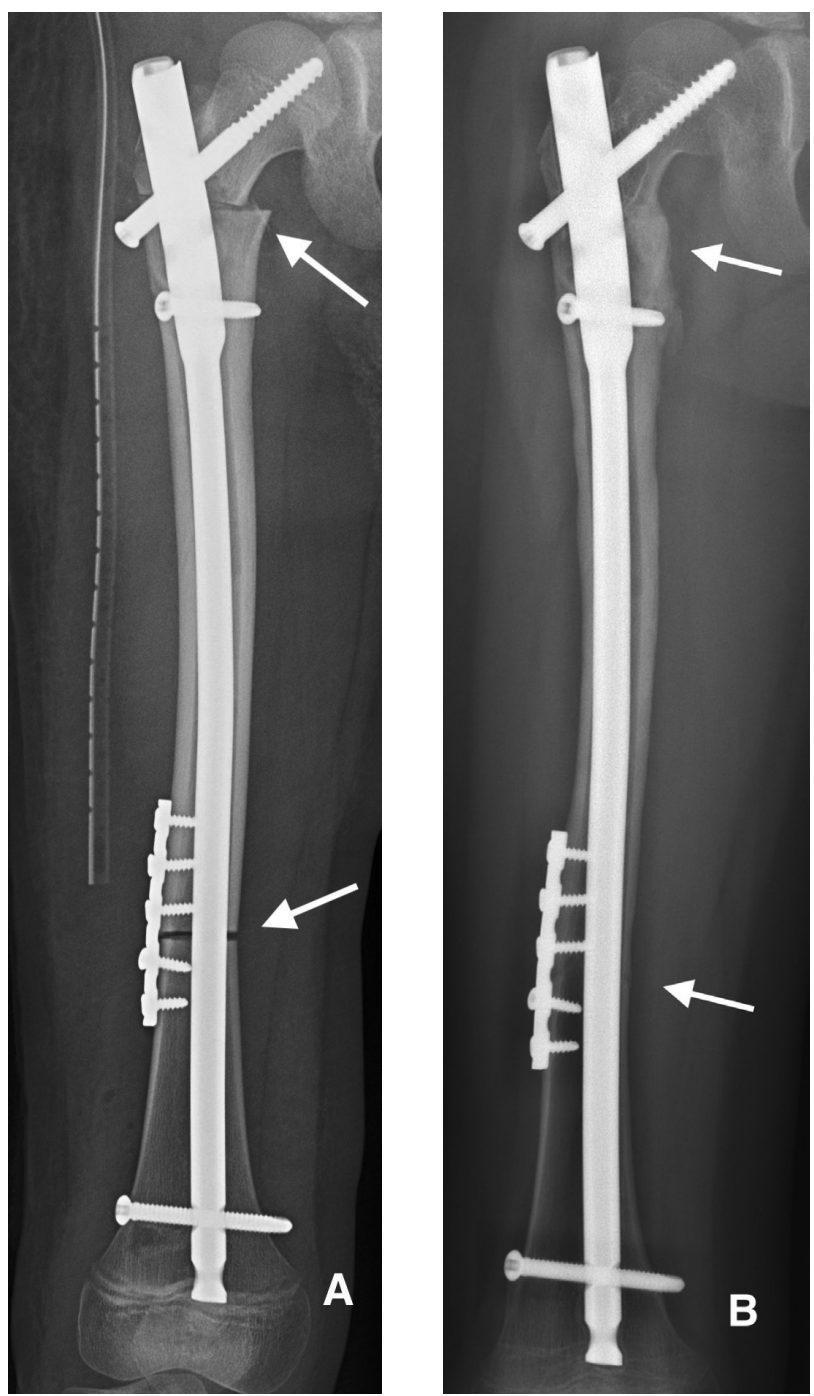

1. ábra

(A) A 10 éves gyermekben a jobb oldali femurdiaphysis $15 \mathrm{~cm}$ es szakaszát érintő Ewing-sarcoma miatt végeztük el a csont re sectióját, majd a besugarazott graft visszaültetését. A rögzítés velőúrszeg és rotációgátló lemez segítségével történt. A nyilak a resectiós síkokat jelölik. (B) 12 hónappal a mútét után igen jó átépülés figyelhető meg mind a proximalis, mind a distalis resec tiós síkban. A gyermek a végtagját teljes testsúllyal terhelve pa naszmentesen jár, végtaghosszkülönbség nincs 


\section{Eredmények}

Mind a 12 esetben teljesült az onkológiailag radikális, végtagmegtartó mútét. A korai posztoperatív szakban szövődményt nem észleltünk. A betegeket 10-12 nappal a mútétet követően otthonukba bocsátottuk.

Tumorrecidíva miatt a későbbiekben egy esetben kellett femoralis amputatiót végeznünk. Itt nem a korábbi mútéti területen alakult ki recidíva, hanem a szomszédos csontban jelentkezett skip ('ugró') metastasis, amely nem tette lehetővé újabb végtagmegtartó mủtét elvégzését. A többi betegnél lokális tumorkiújulást nem észleltünk.

A besugarazott graft teljes eltávolítására egy esetben volt szükség intraarticularis distalis femur resectiót követően, kiterjedt csontnekrózis, következményes grafttörés miatt. Ez esetben a második ülésben egyedi gyártású növekedési tumorprotézis beültetése történt egy évvel a primer mütétet követően. Részleges graftresectiót egy esetben végeztünk álízület kialakulása miatt. Ekkor újabb homológ csontgraft felhasználásával stabilizáltuk a proximalis tibiát, és teljes átépülést sikerült elérni.

A graft részleges vagy teljes eltávolítása során mindig elvégeztük a csont szövettani vizsgálatát. A szegmentumokban recidív vagy aktív, élő tumorszövet nem volt kimutatható. Viabilis sejteket mutattak ki a proximalis resectiós síknál, azonban a graft diaphysealis és distalis területein csak elhalt velóűri sejtek és élettelen hialinporc volt kimutatható

1. táblázat | A Semmelweis Egyetem Ortopédiai Klinikáján 2013 és 2019 között malignus csonttumor miatt extracorporalis irradiatio technikával operált, 12 évesnél fiatalabb gyermekek mútéttel kapcsolatos adatai

\begin{tabular}{|c|c|c|c|c|c|}
\hline Beteg & Lokalizáció & $\begin{array}{l}\text { A rögzítés } \\
\text { típusa }\end{array}$ & Szövődmény & Reoperáció & $\begin{array}{l}\text { Után- } \\
\text { követés } \\
\text { (hónap) }\end{array}$ \\
\hline 1. & Tibia & Lemez & Álízület & Új graft & 73 \\
\hline 2. & Tibia & Lemez & $\begin{array}{l}\text { Szeptikus, } \\
\text { álízület }\end{array}$ & Fémkivétel & 66 \\
\hline 3. & Humerus & Lemez & $\begin{array}{l}\text { Lágyrész- } \\
\text { elégtelenség }\end{array}$ & Nem & 56 \\
\hline 4. & Femur & Velőürszeg & Szeptikus & Nem & 51 \\
\hline 5. & Femur & Lemez & $\begin{array}{l}\text { Grafttörés } \\
\text { traumára }\end{array}$ & Lemez & 36 \\
\hline 6. & Femur & Velőûrszeg & $\begin{array}{l}\text { 'Skip' } \\
\text { metastasis }\end{array}$ & Amputatio & 30 \\
\hline 7. & Femur & Velő"úrszeg & Nincs & Nem & 24 \\
\hline 8. & Femur & Lemez & $\begin{array}{l}\text { Arthrofibro- } \\
\text { sis }\end{array}$ & Nem & 23 \\
\hline 9. & Femur & Lemez & $\begin{array}{l}\text { Arthrofibro- } \\
\text { sis, resorptio }\end{array}$ & $\begin{array}{l}\text { Resectio, } \\
\text { növekedési } \\
\text { protézis }\end{array}$ & 23 \\
\hline 10. & Femur & Velőürszeg & Nincs & Nem & 20 \\
\hline 11. & Femur & Lemez & Nincs & Nem & 3 \\
\hline 12. & Tibia & Lemez & Nincs & Nem & 2 \\
\hline
\end{tabular}

Osteochondralis graft esetében viabilis osteoblastokat, regenerációt észleltünk a porcfelszín degenerációjával.

Három esetben tapasztaltuk álízület kialakulását (25\%), kétszer proximalis tibiaresectiót követő szeptikus folyamat miatt, egyszer distalis femuron a graft resorptiója miatt.

Infekció három esetben (25\%) jelentkezett, mindhárom esetben újabb mútétet végeztünk a graft megtartása mellett. A mútétek során megtörtént a fémanyagok és a nekrotikus csontdarabok teljes eltávolítása, majd lágyrész-rekonstrukciót végeztünk izomlebeny-plasztika és bőrplasztika segítségével. Tartós antibiotikumkezelés mellett minden esetben teljes gyógyulást tapasztaltunk.

Egy esetben észleltük a graft késői törését a mútétet 1,5 évvel követően, ez azonban adekvát traumára következett be, nem hozható összefüggésbe az irradiatióval. Lemezes osteosynthesis mellett a graft meggyógyult.

Két esetben végeztünk intraarticularis resectiót: a hosszan tartó immobilizáció (6 hónap) során mindkét esetben jelentős ízületi mozgásbeszúkülést észleltünk, melynek oldása igen nehézkes. Mindkét betegnél 40 fokos extenziós térdízületi contractura maradt vissza.

A betegek fontosabb adatait az 1. táblázat foglalja össze.

\section{Megbeszélés}

Malignus tumor miatt végzett végtagmegtartó mútét során több fó szempont is döntő a megfelelő mútéti technika megválasztásakor. A legfontosabb a tumor minél radikálisabb eltávolítása a lokális recidívák megelőzésére. Amennyiben a végtag megtartható, fontos a megfelelő funkció biztosítása, valamint a lehetséges szövődmények, későbbi reoperációk számának minimalizálása. A betegeknél, különösen a 12 évesnél fiatalabb pácienseknél sokszok igen nehéz az ideális mútéti terv felállítása. Protézisbeültetés kevéssé merül fel a kis fizikai méretek, a megfelelő implantátumok nehéz elérhetősége, magas ára és a várhatóan magas infekciós és mechanikai szövődményarány miatt. A gyermekek növekedése mellett gyakori a protézis aszeptikus lazulása, és a várható jelentôs végtaghosszkülönbség miatt elsősorban növekedésitumorprotézis-rendszerek jönnek szóba. Ezeknél az implantátumoknál az említett szövődmények még magasabb arányban jelentkeznek. A hagyományos tumorprotézisek 6-10\%-os lazulási, 5-12\%-os szeptikus rátájához és $80 \%$ feletti 5 éves protézistúléléséhez [3] képest a növekedési protézisek esetén igen magas, akár 80-200\%-os reoperációs arányt, $50 \%$ alatti 3 éves protézistúlélést is leírtak már a nemzetközi irodalomban $[15,16]$. Nem elhanyagolható a növekedési protézisek igen magas ára (8-10 millió forint), illetve az, hogy ezen implantátumok még fejlesztés alatt állnak, nincs velük publikált, hosszú távú utánkövetési eredmény. Megfelelő betegeknél a biológiai rekonstrukció jó grafttúlélést és megfelelő funkciót biztosíthat. Népszerú megoldás friss vagy fagyasztott allograftok alkalmazása, a kis méret miatt akár 
egyedi készítésű protézissel kombinálva kompozit formájában, mely biztosítja a reszekált szegment pótlását, a leválasztott izmok és szalagok visszarögzítési pontjait. A technika alkalmazása során a hagyományos tumorprotézisekhez hasonló infekciós (10\%) és tumorrecidíva- (1$5 \%$ ) arányokat találunk a szakirodalomban, azonban az implantátum (graft) jelentősen magasabb, akár 30-40\%os törési arányával kell számolni $[7,8]$. Az allograftok felhasználását tovább nehezíti, hogy alkalmazásukhoz jól múködő csontbankra van szükség, amelyben mindig többféle méretú és formájú graft kell, hogy rendelkezésre álljon. Ezek azonban rendszerint felnőtt donorokból származnak, így gyerekbe nem ültethetők a méretkülönbség miatt. Megoldás a problémára a reszekált, irradiált, orthotopicus autológ graftok használata, mivel így nincs szükség a tárolásukra. Méretük megfelelő, és a csontot az eredeti helyére ültetjük vissza, tökéletes illeszkedést biztosítva. Mint minden tumorsebészeti beavatkozásnál, ezen mútéteknél is a radikalitás a legfontosabb szempont. Különböző nemzetközi centrumokban másmás dózissal (50-300 Gy) végezték a graft besugarazását. Hisztológiai vizsgálatok 60 Gy sugárdózis felett teljes tumornekrózist igazoltak [17]. Biomechanikai vizsgálatok során kimutatták a csont-ásványianyag csökkenését, a kollagén-keresztkötések és az elasztikus modulus emelkedését. 35000 Gy sugárdózis alatt nincs különbség a graft plaszticitásában, viszkoelaszticitásában, rigiditásában $[13,18]$. Mi a 100 Gy egyszeri dózist találtuk a legbiztonságosabbnak. Ekkora sugárzás daganattípustól függetlenül teljes nekrózist okoz, természetesen a graft saját sejtjeit is beleértve. Így strukturálisan stabil, élő sejtektől mentes, avitális vázat kapunk.

A nagy méretú irradiált graftok gyógyulási ideje jelentősen hosszabb a normális csontgyógyulásnál. Legalább 1-1,5 év, amire a kemoterápiának is kedvezőtlen hatása van. Más szerzőkhöz hasonlóan $[6,9] \mathrm{mi}$ is észleltük idővel a graft gyengülését, de amelyik szegment átépült, az később már stabil maradt. Nagy osteolysissel járó tumorok esetén a tumor okozta destrukció által meggyengült autológ graft használata során sikertelenség várható. A megfelelő stabilitás mellett a resectiós síkok átépülése is nélkülözhetetlen a jó funkció eléréséhez. Intercalaris pozícióban leginkább nagy merevségú, áthidaló lemezek használata javasolt [6]. Nekünk kedvező tapasztalataink vannak intramedullaris rögzítéssel, velőưrszegezéssel kapcsolatban is. Rövid, csak a resectiós síkot rögzítő lemezek használatát nem javasoljuk, mert mind az álízület kialakulása, mind a grafttörés nagyobb valószínúséggel következhet be. Több szerző $[6,19]$ kis arányban, 4-9\%ban írta le álízület kialakulását, ami megfelel a mi tapasztalatainknak is, bár rövidebb utánkövetési idő alatt.

Osteoarticularis graftok esetében gyorsan kialakuló arthrosissal lehet számolni [6], valamint a visszarögzített lágy részek, szalagok instabilitásával. Az arthrosis azonban kevesebb panaszt, fájdalmat okoz, mint a szokványos formáknál. Nehéz az ideális immobilizációs idő meghatározása, mivel a túl rövid idejü rögzítés lágyrész- instabilitáshoz vezethet, a túl hosszú merevítés során az ízületi funkciót korlátozó arthrofibrosis alakulhat ki.

Infekció szempontjából meglehetően szélsőséges szakirodalmi adatok születtek, 6-32\%-ban jelentettek korai vagy késői szeptikus komplikációt $[6,19,20]$. Mi az eseteink ötödében észleltünk infekciót, amely újabb bevatkozást igényelt. Graft eltávolítására nem volt szükség, a fémanyag részleges vagy teljes eltávolítása alapos débridement mellett elégségesnek bizonyult.

$\mathrm{Az}$ ismertetett, mind a tumorprotézisekhez, mind az allograftokhoz mérten hasonló szövődményarányok mellett minden szerző hosszú távon magas, 35-45\%-os revíziós rátát írt le $[6,19,20]$. Ezen magas reoperációs arányok az egyes komplikációk összeadódására vezethetők vissza. Összességében a hagyományos tumorprotézis-revíziós arányokhoz hasonló reoperációs rátát eredményezett, csak rövidebb utánkövetési idő alatt [3]. A szükséges reoperációk, revíziók azonban jellemzően kisebb beavatkozások, mint egy tumorprotézis cseréje. Szövődménymentes esetben a technika életre szóló, további mütéteket nem igénylő rekonstrukciós lehetőség, míg tumorprotézis beültetése esetén biztosan szükség lesz a későbbiekben revíziókra.

Gyermekeknél 12 éves kor alatt további várható szövődményforrás az évek alatt kialakuló végtaghosszkülönbség. Intercalaris pozícióban, amennyiben mind a proximalis, mind a distalis epiphysis megtartható, vagy csak átmenetileg detizált, jelentős hosszkülönbség nem alakul ki. Amennyiben egyéb probléma miatt nem kell a graftot eltávolítani, akár élethosszig tartó, stabil csontpótlást lehet létrehozni újabb mútétek nélkül, jó funkcióval. Osteoarticularis graft esetében, vagy amennyiben az egyik epiphysist le kell zárni a megfelelő fixáláshoz, nagyobb méretü, 2-15 cm-es végtaghosszkülönbség is kialakulhat a beteg 16-18 éves korára. Ez kedvezőtlen biomechanikai, funkcionális vagy esztétikai helyzetet okozhat, újabb mútéteket tehet szükségessé. A legegyszerúbb esetben ez ellenoldali epiphyseodesissel csökkenthető, illetve szóba jöhet még a nem érintett csontszegmentum hosszabbítása is. Fontos szempont, hogy az igen fiatal betegeknél a visszaültetett irradiált autograft alkalmazásával lehetôség nyílik - amputatio helyett - megvárni, amíg a csont el nem éri a megfelelő érést, a végleges vastagságát (megfelelő funkciójú, terhelhető végtag mellett). A várakozás során további lehetőség nyílik módszerváltásként tumorendoprotézis beültetésére, akár a végtaghosszkülönbség kiegyenlítése, akár egyéb szövődmények (graftkollapszus, csontnekrózis stb.) megoldására.

\section{Következtetések}

A malignus csonttumorok miatt végzett mütétek mindig nagy kihívást jelentenek az operatőr számára. A legfontosabb szempont továbbra is a tumor minél radikálisabb eltávolítása önmagában vagy a szükséges neoadjuváns kezelést követően. Amennyiben a feltételek adottak, és 
lehetőség van végtagmegtartó mütétre, törekedni kell arra, hogy a végtag rövid és hosszú távon is jó funkcióval múködjön. Minimalizálni kell a lehetséges szövődményeket, a későbbi reoperációk számát. Felnőttkorban a leggyakrabban alkalmazott, legkedvezőbb szövődményaránnyal járó megoldás a tumorprotézis-beültetés. Gyermekeknél számolni kell a növekedés során kialakuló végtaghosszkülönbséggel, a csontok felszívódásával, aszeptikus lazulással. Elsősorban a csontok mérete miatt 6-8 éves kor felett csak egyénre szabott, speciális növekedési protézis beültetése jön szóba, a hagyományosnál lényegesen magasabb szövődményaránnyal. Megfelelő köztes megoldásnak bizonyult a tumoros csontszegmentum széles resectiója, extracorporalis irradiatiója, majd az így kapott autológ graft reimplantatiója. A többi módszerhez hasonló szövődmények mellett meghatározó késői probléma lehet a kialakuló végtaghosszkülönbség, mely a végleges funkciót kedvezőtlenül befolyásolja. A várható méretkülönbség azonban még így is kisebb, mint ha tumorprotézis beültetésével az ízülethez tartozó mindkét epiphysist lezárnánk. A várható szövődményarány pedig még mindig alacsonyabb a növekedési protézisek esetében leírtaknál. Összességében véve az ECI-t jó rekonstrukciós módszernek tartjuk fiatal gyermekeknél. Használatával elkerülhető a növekedésiprotézis-beültetés. A grafttal lehetőség adódik jó végtagi funkció megtartására, amíg lezárul a gyermek növekedése. A későbbiekben szükség esetén pedig már megoldható a konvencionális tumorprotézis beültetése.

Anyagi támogatás: A közlemény megírása anyagi támogatásban nem részesült.

Szerzői munkamegosztás: A szerzók azonos mértékben járultak hozzá a kézirat elkészítéséhez. A cikk végleges változatát valamennyi szerző elolvasta és jóváhagyta.

Érdekeltségek: A szerzőknek nincsenek érdekeltségeik.

\section{Irodalom}

[1] Pakos EE, Nearchou AD, Grimer RJ, et al. Prognostic factors and outcomes for osteosarcoma: an international collaboration. Eur J Cancer 2009; 45: 2367-2375.

[2] Bielack SS, Kempf-Bielack B, Delling G, et al. Prognostic factors in high-grade osteosarcoma of the extremities or trunk: an analysis of 1,702 patients treated on neoadjuvant cooperative osteosarcoma study group protocols. J Clin Oncol. 2002; 20: 776790 .

[3] Capanna R, Scoccianti G, Frenos F, et al. What was the survival os megaprostheses in lower limb reconstructions after tumor resections? Clin Orthop Relat Res. 2015; 473: 820-830.

[4] Bus MP, van de Sande MA, Fiocco M, et al. What are the longterm results of MUTARS ${ }^{\circledast}$ modular endoprostheses for recon- struction of tumor resection of the distal femur and proximal tibia? Clin Orthop Relat Res. 2017; 475: 708-718.

[5] Gosheger G, Gebert C, Ahrens H, et al. Endoprosthetic reconstruction in 250 patients with sarcoma. Clin Orthop Relat Res. 2006; 450: 164-171.

[6] Poffyn B, Sys G, Mulliez A, et al. Extracorporeally irradiated autografts for the treatment of bone tumours: tips and tricks. Int Orthop (SICOT). 2011; 35: 889-895.

[7] Muscolo DL, Ayerza MA, Farfalli G, et al. Proximal tibia osteoarticular allografts in tumor limb salvage surgery. Clin Orthop Relat Res. 2010; 468: 1396-1404.

[8] Bus MP, Van de Sande MA, Taminiau AH, et al. Is there still a role for osteoarticular allograft reconstruction in musculoskeletal tumour surgery? A long-term follow-up study of 38 patients and systematic review of the literature. Bone Joint J. 2017; 99: 522530.

[9] Wheeler DL, Enneking WF. Allograft bone decreases in strength in vivo over time. Clin Orthop Relat Res. 2005; 435: 36-42.

[10] Enneking WF, Campanacci DA. Retrieved human allografts: a clinicopathological study. J Bone Joint Surg Am. 2001; 83: 971986.

[11] Gupta A, Meswania J, Pollock R, et al. Non-invasive distal femoral expandable endoprosthesis for limb-salvage surgery in paediatric tumours J Bone Joint Surg Br. 2006; 88: 649-654.

[12] Uyttendaele D, De Schryver A, Claessens H, et al. Limb conservation in primary bone tumours by resection, extracorporeal irradiation and re-implantation. J Bone Joint Surg Br. 1988; 70: 348-353.

[13] Gupta S, Cafferky D, Cowie F, et al. The mechanical effects of extracorporeal irradiation on bone. Bone Joint J. 2015; 97: $1152-1156$.

[14] Szendrói M, Antal I, Kiss J, et al. Contemporary management of bone tumors at the Department of Orthopedics of the Semmelweis University. [Csonttumorellátás a Semmelweis Egyetem Ortopédiai Klinikáján.] Magy Onkol. 2014; 58: 88-93. [Hungarian]

[15] Henderson ER, Pepper AM, Marulanda G, et al. Outcome of lower-limb preservation with an expandable endoprosthesis after bone tumor resection in children. J Bone Joint Surg Am. 2012; 94: 537-547

[16] Ness KK, Neel MD, Kaste SC, et al. A comparison of function after limb salvage with non-invasive expandable or modular prostheses in children. Eur J Cancer 2014; 50: 3212-3220.

[17] Hatano H, Ogose A, Hotta T, et al. Extracorporeal irradiated autogenous osteochondral graft: a histological study. J Bone Joint Surg Br. 2005; 87-B: 1006-1011.

[18] Chauhan S, Manoj K, Rastogi S, et al. Biomechanical investigation of the effect of extracorporeal irradiation on resected human bone. J Mech Behav Biomed Mater. 2017; 65: 791-800.

[19] Hong AM, Millington S, Ahern V, et al. Limb preservation surgery with extracorporeal irradiation in the management of malignant bone tumor: the oncological outcomes of 101 patients. Ann Oncol. 2013; 24: 2676-2680.

[20] Hayashi K, Araki N, Koizumi M, et al. Long-term results of intraoperative extracorporeal irradiation of autogenous bone grafts on primary bone and soft tissue malignancies. Acta Oncol. 2015; 54: 138-141

(Perlaky Tamás dr., Budapest, Üllői út 78/b, 1085 e-mail: pertamas@hotmail.com)

A cikk a Creative Commons Attribution 4.0 International License (https://creativecommons.org/licenses/by/4.0/) feltételei szerint publikált Open Access közlemény, melynek szellemében a cikk bármilyen médiumban szabadon felhasználható, megosztható és újraközölhető, feltéve, hogy az eredeti szerző és a közlés helye illetve a CC License linkje és az esetlegesen végrehajtott módosítások feltüntetésre kerülnek. (SID_1) 